1993

\title{
A Musical Retrieve of Heidegger, Nietzsche, and Technology: Cadence, Concinnity, and Playing Brass
}

Babette Babich

Fordham University, babich@fordham.edu

Follow this and additional works at: https://fordham.bepress.com/phil_babich

Part of the Continental Philosophy Commons, $\underline{\text { Rhetoric Commons, and the Science and }}$ Technology Studies Commons

\section{Recommended Citation}

Babich, Babette, "A Musical Retrieve of Heidegger, Nietzsche, and Technology: Cadence, Concinnity, and Playing Brass" (1993). Articles and Chapters in Academic Book Collections. 4.

https://fordham.bepress.com/phil_babich/4 


\title{
Articles
}

\section{A musical retrieve of Heidegger, Nietzsche, and technology: Cadence, concinnity, and playing brass}

\author{
BABETTE E. BABICH \\ Department of Philosophy, Fordham University, 113 West 60th Street, New York, \\ NY 10023
}

In what follows, I discuss Heidegger's analysis of the essence of modern technology as a version of what Heidegger names Nietzsche's highest will to power together with Heidegger's understanding of Nietzsche's statement of the nihilism of our day. I suggest that Heidegger's philosophic questioning of technology is necessarily foreclosed by his stylized, hermetic reading of Nietzsche's expression of the will to power. Here I seek to read Heidegger's critique of technology in the light of rather than against Nietzsche's critique of science and culture - that is, to speak Nietzsche's language: "Out of the spirit of music." Thus, it will be necessary to read Heidegger's reading of Nietzsche against Heidegger's reading of Nietzsche. But this is to say that we must learn to read Heidegger. Reading Heidegger against Heidegger, as Michael Theunissen observes, is not only a necessary consequence and preservative against, as Jürgen Habermas contends, Heidegger's damning political convictions, but is in fact the condition sine qua non of a genuine Auseinandersetzung with Heidegger. ${ }^{1}$ In the present essay, I seek to bracket Heidegger's stylistic retrieve of Nietzsche's philosophy of nihilism in the service of the possibility of such an Auseinandersetzung. In the resonance of Nietzsche's jesting reprobation of philosophical conviction, such an Auseinandersetzung does not free us from but rather exposes us to the task of learning how to read, how to think, and - reading and thinking ourselves - how, in the end, to laugh.

\section{Heidegger and Nietzsche reading the reader: Cadence, conviction, return}

Heidegger is read as - Heidegger is accused of - having read Nietzsche against Nietzsche and having done so unfairly, misrepresenting his thought. The charge is that levelled against Heidegger's philosophy in general: Heidegger, it is said, embarks upon contradictory claims concerning philosophers and philosophical traditions, which inaccuracy he fails to note; 
he makes philological claims or traces etymological connections that cannot stand up to closer, expert examination; he uses words and concepts inflatedly, so that his argument rises like a balloon to the heights of obscurity, and so on. All this is particularly damning, it is thought, in the case of Heidegger - a philosopher who matches Aristotle in condemning the entire tradition before himself. For Aristotle, no earlier thinker had ever managed to think the comprehensive, precise definition of a concept or a term, be that term friendship or the nature of the good. For Heidegger, beginning as he does from Brentano's expression of the manifold sense of Being in Aristotle, the tradition as a whole from the Greeks onward has failed to think the essence of or the question concerning Being. In turn, for readers critical of Heidegger, this failure to think Being is as nothing compared with the meaninglessness of Heidegger's project.

I expect to be able to show why such anti-Heideggerian criticism misses the point of Heidegger's reading of philosophy in general by considering the rather more demanding case of Heidegger's reading of Nietzsche. What makes this case more demanding is not, contrary to Eric Blondel's assertion, the volume of Heidegger's work on Nietzsche. Rather what is problematic here is Nietzsche himself. ${ }^{2}$ If any author has "made good" his own predictions concerning his post-humous quality, his destined timeliness for a coming era, it is Nietzsche. Where Shakespeare's sonnets are remarkable not for their subject extolling the singular virtues of his love but for his recurrent egoism, proclaiming the eternal potency of the poet's word, Nietzsche is hardly the first author to promise himself a destiny. What makes Nietzsche so unusual is not the audacity of his proclamation but the evidence for his claim, shown again and again in spite of and not on the terms of his readers. If some could argue that Shakespeare's immortal words have been blurred by the amber of authority, Nietzsche remains alltoo current. This is so despite the then-timeliness, that is, the historical context which may plainly be read, for example, from the table of contents of Beyond Good and Evil: "The Free Spirit," "The Religious Nature," "On the Natural History of Morals," or "Peoples and Fatherlands." Taking off from the very German and historical circumstances of his cultural references and themes, Nietzsche nonetheless manages to speak as a European and is rather more untimely, continually, renewedly untimely than can be imagined for him to have been, as Rüdiger Safranski rather credulously suggests, only a child of his "wissenschaftsgläubigen Zeitalters." ${ }^{3}$ If Nietzsche can do this, if Nietzsche can still speak to us, if he can thus be part of our untimely destiny, as all the evident and continuing currency of his name suggests, one would be remiss if one did not ask how Heidegger gets off including Nietzsche within the scheme of Western Metaphysics? 
What Heidegger does with Nietzsche is, of course, what he does with other philosophers, where Heidegger's modus operandi routinely involves such summary and denigrating points of departure. Accordingly, Being and Time begins with double irony, that is with an ironic citation from Plato that took Plato rather too much at his word: from then on, the battle of the giants concerning Being is one which Plato and Aristotle incorporate but were unable to decide. ${ }^{4}$ Heidegger alone, it would seem, and Heidegger's interpreters underline this point to the predictable vexation of readers with other philosophic tastes, is the one who can restore the question of Being as a question and follow it. Nietzsche will be read on the same misappointed terms. Moreover, by condemning Nietzsche as the last metaphysician of the West, particularly with reference to the question concerning technology, reading Nietzsche as the advocate of dominion (Herrschaft) over the earth embodied in the doctrine of will to power and the proclamation of the Übermensch, Heidegger seems to sidestep the very confrontation he proposes as essential for thought in general and he himself identifies as characteristic of his lectures on Nietzsche in particular.

Yet Heidegger's reading of Nietzsche is an apposite rather than a failed confrontation and we can see why if we consider Heidegger's own stylistic strategy and, having adverted to it, identify its movement. Like Nietzsche here, Heidegger explicitly addresses what is troublesome in the reading he articulates (this is the cadence of his reading: where the claim is posed as it falls, and falls out inappropriately to the ear of the reader). Like Nietzsche too, Heidegger then pushes the dissonance of the pronouncement so that he himself seems to anticipate - and more harshly if anything - the objections a careful or discontented reader might make (this is the intensification or conviction of his reading: where the claim is carried to an extreme, and not only so that there is no mistake about it). Finally, and here he departs from Nietzsche stylistically if not modally, Heidegger retrieves the fallen, nowcharged expression for the turning of his point (this is the recuperation or return of his reading: where the first point is repeated in the direction of the tonality to be heard, apart from but also through the ambiguity of language, that is, thoughtful expression). To follow Heidegger, as to follow Nietzsche, requires that the reader be prepared to think along with the thinker. Now almost any philosophy will reward a careful reading, given attention to what is or perhaps better could be meant along with the usual reading adverting to the overlooked, the underemphasized, the misunderstood. But Nietzsche and Heidegger for their part anticipate the critical reader's response and that not merely as Aristotle had done, or the scholastic tradition thereby influenced, that is, not merely formally. Rather than thinking on the terms of the argument advanced of opposition formally implicit in its expression or else contingent upon the meanings of its terms, 
and so on, Nietzsche and Heidegger are provocative, where this last characteristic features most plainly in Nietzsche's style.

If the stylised didacticism of the above procedure of cadence, conviction, and return may also be found throughout Heidegger's writings, it is especially characteristic of Heidegger's reading of Nietzsche. Thus where Heidegger (notoriously) claims that Nietzsche is a thinker within (if also at the end as the culmination of) Western metaphysics, he adverts to the reader's problems with this position from the start. In the first section of his two volume study of Nietzsche then, titled so that no one can miss the point to be made: "Nietzsche as Metaphysical Thinker," Heidegger claims the question "What is being?" as the metaphysical question par excellence and maintains that "Nietzsche's thinking proceeds within the vast orbit of the ancient guiding question of philosophy," that is, the question of metaphysics. ${ }^{5}$ The anticipatory cadence is no harder to track here than the force of Heidegger's claim itself reflected in the section's title. The cadence begins with the very next sentence: "Is Nietzsche then not at all so modern as the hubbub that has surrounded him makes it seem?"6 That this query is not merely rhetorical is indicated by its intensification: "Is Nietzsche not nearly so subversive as he himself was wont to pose?" Here the beginning of the return follows as quickly in the next sentence: "Dispelling such fears is not really necessary; we need not bother to do that." With this Heidegger introduces the concession needed to understand the point of the radicality of the first claim despite its apparent direction or anticipatory implication. Thus if the falling out (which I am calling the cadence) of Heidegger's claim that Nietzsche's thought "proceeds within the vast orbit of the ancient guiding question of philosophy, "What is being?" is the intensifying claim that perhaps Nietzsche is less than modern, less subversive than had been thought, the recuperation of Heidegger's position is clear in the concession that has been more important for the very fact of subsequent Nietzsche scholarship than almost any other expression of his thought, for with this Nietzsche's thought is claimed neither for modern or modish nor for subversive thought but rather for and as philosophy. ${ }^{7}$ What is recuperated then is patent: "the reference to the fact that Nietzsche moves in the orbit of the question of Western philosophy only serves to make clear that Nietzsche knew what philosophy is."8

Heidegger will spend the rest of his Nietzsche reading repeating this claim along with its implications. Thus if Heidegger claims as he does that "If in Nietzsche's thinking the prior tradition of Western thought is gathered and completed in a decisive respect," we as readers not only of Heidegger but also of Nietzsche may not dispense with the necessity of reading and reflecting, of thinking back on what has been read as we read forward. Thus we do not stop with the consequent continuation of the above implica- 
tion, that is, Heidegger's own project in reading Nietzsche, wherein "the confrontation with Nietzsche becomes one with all Western thought hitherto." We may not stop there because the meaning of "confrontation" as Auseinandersetzung, that is, as interpretation or Auslegung, for Heidegger is itself decisive for his thought and for the thinking of philosophy. Confrontation "is the supreme way, the only way, to a true estimation of a thinker." The approximative expression is fortuitous, . where for Heidegger, the "confrontation with Nietzsche has not yet begun." In a preface written in 1961, the confrontation is still a matter for preparatory thought, still an issue as to whence "the "Nietzsche matter" comes and wither it goes" which the reader may only decide in the same way, that is, by thinking. ${ }^{9}$

Is the point to be made here that Heidegger's reading of Nietzsche is not as abusive as it seems - which would seem to concede the direction of a reading rather like what $I$ have named, as the first tack of a Heideggerstyled cadence and in the already cadenced context then, an already decadent, already intensified point posed for a recuperation: but then all too rhetorically posed to work (that is to have any rhetorical effect)? Yes and no. For while Heidegger does not quite force the account on Nietzsche that he has been taken to have done, he does both use and abuse the style of claiming against ordinary convictions to bring the force of those convictions to light and thus advance the path of thought beyond such convictions. The effect of the abuse of this tactic works against Heidegger, as against a thinker who sought to think the complex side of truth in its ambiguity and its mystery in what he called the clearing, the open. Thus Heidegger is known for his obscurity. Nietzsche who sought to show his own darkness by claiming allegiance with Heraclitus - the thinker of shadow and contradiction, daimonic character, cleansing fire, and the rule of logos - is known as the most easily understood, the most fun, the paperback, readilyread, readily-quotable philosopher whose writings seem to work as well for bathroom graffiti [God is Dead] as for introducing Conan, the Movie [What does not kill me makes me stronger] as for prefacing chapters in new-age self-help books [The two prior citations along with a selection of apothegms on truth, destiny, and diet]. Such is fate. But I have sought to suggest that Heidegger's problem is not that he misses Nietzsche's point. Instead Heidegger's uses Nietzsche's insights against Nietzsche to advance Heidegger's own project. It does not really speak against this strategy that Heidegger was not able to completely read Nietzsche over to his own project, that Heidegger borrowing not only Nietzsche's insights concerning the reader for his authorial venture, his own strategic path of thinking, but also Nietzsche's understanding of the nature of truth, should overreach himself. It is an ancient Greek and mystical truism that condemned Heideg- 
ger's efforts here, a truth reflecting a spirit and a vengeance both Heidegger and Nietzsche could have admired.

\section{Heidegger and the truth of technology}

The question concerning technology is a question concerning the truth of technology, a questioning following upon, asking after technology in its truth as destiny. But truth, conceived esoterically as aletheia, "is in a lofty sense ambiguous. Such ambiguity points to the mystery of all revealing." 10 For Heidegger, truth is unconcealment. In thinking truth "as the unconcealedness of beings," 11 Heidegger turns to stress the concealed, prevailing "in the midst of beings a twofold way." (WA 53) The ambiguous happening of truth as unconcealment reveals what is, while at the same time concealing itself, which brings us to the familiar Heideggerian issue: "That which is, the particular being, stands in Being." (WA 53) This is the realm in which "every being stands for us and from which it withdraws." (WA 52)

The truth of technology is the address of truth, the inherently ambiguous domain of the happening of truth. And mortal truth is ambiguous in just the way that technology is ambiguous where both can be conceived as a destining of revealing. The danger of technology, of Ge-Stell, here understood as Betrieb and as inherent in the essence and destiny of technique is its denial of truth and human freedom conceived as resolute attention and openness to the realm of destining. (QT 25) This is the danger that threatens the truth of technology and the truth of revealing. Heidegger writes: "Enframing, in a way characteristic of a destining, blocks poiesis." [Das Ge-Stell verstellt das Scheinen und Walten der Wahrheit.] (QT 30) What is blocked [verstellt] is the esoteric height or "lofty ambiguity" of truth. What is left, what remains, is the way of calculating representation, that is, truth reduced or leveled to the impoverished singularity of the "correct:" "Enframing blocks the shining-forth and holding-sway of truth." (QT 28) This is named the extreme danger of Enframing. Yet Heidegger also says that this very blocking, the excluding of ambiguity that belongs to the very essence of technological precision, because it is the danger inherent in a destining of revealing, is also the saving possibility. ${ }^{12}$

For Heidegger, the capital perspectival precision of phenomenology concerns the essence of truth, of manifestation as what shows itself, phainesthai, and obscures itself in shining forth as what is revealed. The reader has heard all this before: unconcealment conceals concealment. This is the essential ambiguity of technology as a way of revealing that points to the mystery of essence as such. Thus for Heidegger, "the unconcealment in which everything that is shows itself at any given time harbors the danger 
that man may quail at the unconcealed and thus misinterpret it." (QT 26) What makes Enframing, as the essence of technology dangerous is, as we have seen, two-fold. By speaking of revealing as two-fold Heidegger does not articulate a humanism or subjectivism. What is unconcealed always conceals, but this is not just a feature of human prejudice or phenomenological objectivity: rather this concealment, this veiling intrinsic to revelation, belongs to the essence of what Heidegger calls truth. Revelation is the shining forth of what is as it is, and it is this shining forth that conceals what remains hidden and this has nothing to do with the point of view of the one who beholds what is thus revealed if this one is also claimed to witness what is at it is, and not for the sake of any accurate observation.

Human beings are ever (in essence) given over to belong to the coming to pass of truth. In this way, the "saving power" Hölderlin speaks of is expressed by Heidegger as precisely that which "lets man see and enter into the highest dignity of his essence... Keeping watch over the unconcealment - and with it, from the first, the concealment - of all coming to presence of this earth." (32) For Heidegger, what is endangered is the aletheic, poetic essence of truth, the veiled essence of truth, an insight he has from Nietzsche, where he can say almost as Nietzsche would: "Truth is un-truth" (WA 55) and mean, with reference to poiesis, to poetry, and the poet already named, "Truth as the clearing and concealing of what is, happens in being composed, as a poet composes a poem." (WA 72) For Heidegger, the question concerning technology, the dangerous prospect of Enframing reflects at every point the same conjunction between clearing and concealing. ${ }^{13}$ As the poet composes a poem, the thinker here asks after the essence, asks in the wake of, from out of solicitude for, technology. For Heidegger, Hölderlin's expression of the saving power grows from the danger: "Whence something grows, there it takes root, from thence it thrives." (QT 28) This reflection brings us to the original expression of techne in its mythical Greek beginning, as "a revealing that brought forth and hither and therefore belonged within poiesis." (QT 34) In the present essay, "we are summoned to hope in the growing light of the saving power" (QT 33) where "the closer we come to the danger, the more brightly do the ways into the saving power begin to shine and the more questioning we become." (QT 35)

It is precisely because of the reflective piety of questioning that this summons is not to be a mysticism or an apocalyptic eschatology. The "fostering" of the saving power in which we are to hope, which we are to preserve, is only sponsored "Here and now and in little things." (QT 33) What is to be done is to be done "here and now," what must be safegarded, preserved, secured can only be advanced "in little things." Thus, "the more questioning we become," the more "pious" our thinking, the more we may 
forego the vulgar rule of the subject of humanism, domination, the control of the earth. For Heidegger what we forego here returns us to the original essence of techne, "as the bringing forth of the true into the splendor of radiant appearing ... into the beautiful." (AT 34) The small wonder Heidegger enjoins "here and now and in little things" is the very wonder that a thing can be. Yet we may note that because of the growing purview of modern technology, because of the ordinary distance of what is closest to us, to talk of wonder is almost too much, too precious for us.

Like the old philosophic prejudice against poetry, Heidegger finds the modern, rationalistic prejudice at work in the same way in his reading of Hölderlin's promise: “...poetically man dwells..." Heidegger's charged anticipation, cadence, and conviction, is offered, as usual, at the start of his essay. The phrase "...poetically man dwells...," for Heidegger, "comes to us by a curious route." With this initial comment, Heidegger means to read the poem that "beings "In lovely blueness..." but to "restore" the phrase "thoughtfully to the poem," the cadence and concession to the reader affirms "the doubts it immediately arouses." 14 Such doubts speak in the conviction that in a harried world of housing-concerns, "dwelling remain[s] incompatible with the poetic." In the same day-to-day world, poetry is hardly more than "a preoccupation with aestheticizing." Thus for Heidegger, "Poetry is either rejected as a frivolous mooning and vaporizing into the unknown, and a flight into dreamland, or is counted as part of literature." (P 213) Apart from its literary function, which brackets poetry as much as its aestheticization does, and construing poetry as imagination and invention, as making, Heidegger recuperates the poet's phrase to the word. Poetic diction has a precision that is not free fancy: "dwelling" is not "housing." In the cadence conceding the convicted suspicions of the reader, returning to the word, we may begin to see what Heidegger could mean by speaking of the wonder of poetic saying as that which "brings the unsayable as such into a world." (WA 74)

Only in renouncing human self-will can the human be freely "gathered" into what is properly its own [ge-eignet], so that the human may, from "within the safeguarded element of world... as the mortal, look out toward the divine."15 "Otherwise not;" says Heidegger. For in any other wise we would lack the question where "questioning is the piety of thought." (QT 35) Failing to question, we fail to pose the question of thought, we fail to hold true to the task of thinking. Thus Heidegger reminds us that before we may ask "What must we do" we are to ask "How must we think" (QT/T 40), where thinking is "genuine activity." Belonging to Being, "primal corresponding, expressly carried out, is thinking." (QT/T 41) This then is the turning. "The constellation of Being is the denial of the world, in the form of injurious neglect of the thing." (QT/T 49) Yet to say this is to say that the 
world is denied and to say that, again, says nothing new to us. For the postmodern era is nothing if it is not the era of heightened consciousness of the jaded, of lost innocence. The world which the watchful, poetic word preserves and here that is to say, saves, the world, the word is denied within the reigning sphere of modern technology.

But an apocalyptic prediction of the denial of the world and language is not all there is to say and that is why a somehow astonished Heidegger felt it important to assure Richard Wisser during his "Television Interview" that his thinking is not anti-technology. ${ }^{16}$ For Heidegger, "Denial is not nothing." (QT/T 49) Thus Heidegger's invocation and blessing - i.e., the prayer - offered at the end of the essay on the "Turning" is a saying following the question "What must we do?" This saying is offered precisely where "it is the constellation of Being that is uttering itself to us," invoked for those who "do not yet hear, we whose hearing and seeing are perishing through radio and film under the rule of technology." (QT/T 48) The manifold question for thought, "Will insight into that which is bring itself disclosingly to pass? Will we, as the ones caught sight of, be so brought home into the essential glance of Being that we will no longer elude it?" (QT/T 49) can now be unfolded into the blessing of Heidegger's wish.

T. S. Eliot heard this connection, subscribed to us what must be done, as task:

Then spoke the Thunder

DA

Datta: what have we given?

My friend, blood shaking my heart

The awful daring of a moment's surrender

Which an age of prudence can never retract

By this, and this only, we have existed. ${ }^{17}$

What is to be thought here is the meaning of task as what is charged, as Auftrag. This thought can be heard from the mystical heights of Hölderlin's admission at the end of the first version of Der Einzige, "Nie treff ich, wie ich wünsche / Das Maas. Ein Gott weiß aber / Wenn kommet, was ich wünsche das Beste."18 Again, at the conclusion of the later version of Patmos, the poem so important to Heidegger,

...Nemlich rein

Zu seyn, ist Geschik, ein Leben, das ein Herz hat,

Vor solchem Angesicht', und dauert über die Hälfte.

$\mathrm{Zu}$ meiden aber ist viel... ${ }^{19}$

Another more recent poet cries, "Das alles war Auftrag." Rilke claims that the season needs us, the very stars shine only for the consecration of the heart, the song of the violin is offered for the one who in passing 
hears. ${ }^{20}$ What the violin yields is given but what is assigned, what is charged, is set to the one who can rise to match what is given, answering what must be given, preserving the volatile and "awful daring," - the essence of our being for Eliot and which is "not to be found in our obituaries" - mastering as Rilke witnesses to the angel what is assigned us. For Hölderlin, this is to catch oneself gone upon the way one is to go, arced and cast, like "Drachenzähne." All the while observing in song the law that sends one upon that course of poetic preservation, of cultivation, where like fallen wheat "nicht ein Übel ists, wenn einiges/Verloren geht." 21

"We look into the danger and see the growth of the saving power." (QT 33) This dangerous prospect is neither secure nor sure. For what we do when we "look into the constellation of truth," when we attend upon technology in its essence, or question concerning "the constellation in which revealing and concealing, in which the coming to presence of truth comes to pass," (QT 33) is thoughtful, recollective, meditative, poetic watchfulness. And this is hard. What Heidegger in his essay on the "Origin of the Work of Ar" names echoing Hölderlin from the start as "founding preservation" [stiftende Bewahrung] and which in the essay on technology is named in connection with being able to endure [währen] is finally expressed as "what is granted [das Gewährte]." 31 For Heidegger this is what poetry can do: "Projective saying [Entwerfende Sagen] is saying which in preparing the sayable, simultaneously brings the unsayable as such into a world." (WA 74) The nature of art is in this way poetical. Thus techne, in its origin "may awaken and found anew our look into that which grants and our trust in it." (QT 35)

If Heidegger can question the saving power of poetry, of art, of techne as it belongs to poiesis to ask as he does at the end in an intensification without a concession, without explicit return, "Whether art may be granted this highest possibility of its essence in the midst of the extreme danger, no one can tell," (QT 35) it is because the danger here is the danger of failing to wait, to pose and hold the question of the most questionable. Heidegger's final word in "the Turning" is necessarily blessing and prayer: "May world in its worlding be the nearest of all nearing that nears, as it brings the truth of Being near to man's essence, and so gives man to belong to the disclosing bringing-to-pass that is a bringing into its own." (QT/T 49) In connection with poetry, Heidegger explains this that is "man's" own: "man is capable of poetry at any time only to the degree to which his being is appropriate to that which itself has a liking for man and therefore needs his presence." (P 228) 


\section{Nihilism and the question of value}

It is on the terms of a deliberately post-humanistic pluralism of willing being that Nietzsche raises what Heidegger calls the question of Being, addressing the world, the organic, the thought of being and becoming, interpretation, perspective, and event, speaking of history and politics, people and customs, good and evil, men, women, sexuality, and power. ${ }^{22}$ Here, if the postmodern condition of pluralism and fluid tolerance can be said to be good for anything, it might be expected to open our philosophic sensibilities to Nietzsche's recollection of the world of becoming and innocence.

The object of philosophic inquiry for Nietzsche is the desire - the will of everything that is. Conceived as desire or will to power, the will does not characterize the essence of being human as distinguished from the all. Nature or the world, in Nietzsche's celebrated formula is "will to power and nothing else." Nietzsche rejects the fetishistic distinction between humanity and all other ways of being. Reflecting on his own philosophy and its projection, Nietzsche writes "I differentiate not a philosophy of the individual but a hierarchy, a rankordering." This ranging differentiation as will to power is the Anaxamandrian schema of coming into being, that is, of becoming. Presubjective or postsubjective - such becoming must be thought as the Greeks thought it and that does not revolve around anthropomorphic differentiation and dissolution in time, that is, the meaning of becoming is not a vanitas but must be thought as tragic mortality.

What may be named Nietzsche's elitism or hierarchic thinking (a deliberate, willed ranking) is reflected in the schema of Will to Power and is the essence of his philosophic project and his style. ${ }^{23} \mathrm{~A}$ clear articulation of the significance of Nietzsche's elitism is indispensable for an understanding of Nietzsche's discussion of nihilism and values, especially the notion of revaluing or coining values. But to understand elitism here is only to emphasize the notion of difference in feeling and creation, the difference between the will to power born to excess or lack, of abundance or inadequacy.

Heidegger reads Nietzsche's culture-critique as the thought of nihilism conceived as "the inner logic of Western history," 24 culminating in the essence of modern technicity. This consummate nihilism, Nietzsche's creative nihilism of "strength" opposing the desultory nihilism of exhausted ideals, sees the state of vanishing values and seizes for itself the right to remake values, to revalue values, and with this to attain to happiness. Thus Heidegger recalls Nietzsche's ecstatic proclamation of the promise of creators become conscious of themselves - who "think and feel at the same 
time." In Nietzsche's words,

Whatever has value in our world now does not have value in itself, according to its nature, ... and it was we who gave and bestowed it. Only we have created the world that concerns man.... we fail to recognize our best power and underestimate ourselves... We are neither as proud nor as happy as we might be..$^{25}$

Attaining to this proud consciousness in a radical revaluation of values that is Nietzsche's legacy as the creative expression of nihilism gives rise to the supreme danger of the human destining-foreclosing essence of modern technology: the illusion that "everything man encounters exists only insofar as it is his construct." (QT 27) In the Beiträge zur Philosophie, Heidegger calls this consequent illusion of material and cultural mastery, the "Entzauberung des Seienden" - the loss of the enchanting force of everything that is. ${ }^{26}$ We have already seen that by way of the modern era's technologically mediated, self-consummated enchantment (Verzauberung) of humanistic power, confirmed by sheer efficacy in doing, beings lose the magic of being what they are, their thatness or emergent presence. For Heidegger, far from the possibility of the smallest wonder, far from full speech, far from bringing the "unsayable as such into a world" articulated in poetic reticence, or from Heidegger's own preparatory thinking, Nietzsche's cultural analytic of nihilism poses the possibility of the revaluation of values as a Machenschaft of values consciously seized and expressed by the will to power. The darkening force of the age of modern technology follows from its essence in the closure of metaphysics as an expression of what Heidegger takes in Nietzsche's name to be the highest will to power.

Because there are different schemas of inventive human possibility, will to power for Nietzsche may be distinguished according to its original genesis in each case. So far from being at its height as domination, which is not to say self-cultivation, Nietzsche's esoteric conception of the highest will to power articulates a consummately expressed letting-be not unlike Heidegger's thought of Gelassenheit. And, I will suggest, if we are to think Heidegger's expression of the shadowed possibility of redemption or healing interior to the growing danger that is the essential darkness of modern technology as a possibility, we cannot fail to reflect upon, to really ponder and so to catch the evaluative, creative difference, the hierarchy of feeling separating rancor and delight, glum preservation and blessing.

Countering the tenor of Heidegger's reading, Nietzsche's highest will to power is no opposition to becoming, it does not conceive Being as fixed, and by dint of its nature, the highest, creative Will to Power of overweening, overwhelming abundance is foreign to the technological transformation 
of the face of the world in the image of so much raw material for human construction and ready reserve. The redemption Nietzsche's Zarathustra traces in the dark morning sky is the redemption of becoming conceived in the lightning-flash, in contrast with being, with fixity, that is to say: chance. Instead of a designed cosmos or heaven of Reason, Zarathustra descries the heavenly roll of the dice: "Over all things stands the heaven Accident, the heaven Innocence, the heaven Chance, the heaven Prankishness." (Z:III, "Before Sunrise") Such a chance cosmos is nothing but chaos, under the sign of forgiveness, the artifice of the cosmos absolved as artifice, the lightning flash that illuminates becoming redeemed in opposition to the fixity of being.

When we read Nietzsche's analysis of nihilism, we cannot forget that what he does is to ask "what kind of human being" could count as lord of the earth, only to give an answer in terms of the lowest will to power: the will that grows in rancor. Thus Nietzsche's Zarathustra contrasts the "lowest" with the "highest species of all being." The highest, "the most comprehensive soul, which can run and stray and roam farthest within itself, the most necessary soul," is the soul of redeemed or innocent becoming, crowned by the blessing of chance. Such a soul "out of sheer joy plunges itself into chance - having being, [it] dives into becoming." (Z:III O 19) In opposition to this is the lowest species or type of being, the parasite, which Zarathustra also names "the lazy creepers, and all the ravenous vermin." These latter correspond of course to Nietzsche's celebrated, all-too-convenient rabble, whose ways are, we are told over and over again, "dark ways, verily, on which not a single hope flashes anymore. Let the shopkeeper rule where all that still glitters is - shopkeeper's gold... Look how these people are now like shopkeepers: they pick up the smallest advantage from any rubbish." (Z:III O 21)

Beyond the level of the banal or the everyday, there is still a temptation to what Nietzsche calls rancune, the result of absorption and a lack of artistic, creative distance. But if it is hard to read Heidegger reading Nietzsche as he reads Nietzsche for his own purposes, it is harder to read Nietzsche without knowing ourselves and our thinking, without being sure of our purposes. How are we to read Nietzsche, who writes against himself, as against his reader, the Nietzsche who writes for a rare understanding? How are we to read as the bearers of, the seekers of such a rare or elite understanding? How close must one be to oneself to understand Nietzsche's claim already cited from the Gay Science that "we are neither as proud nor as happy as we might be?"

The mischief here is that the closer we are to ourselves, the more ponderously we are likely to take Nietzsche's claims, his warnings, his seductions, and the more likely we are to read the standard relativist schema 
into Nietzsche's suggestion that "only we have created the world that concerns man." The issue of rank order, the position of soul - self-disposition - the nature and kind of Bestimmung required by the self-cultivated artist, the artist of the grand style, calls for an artist's aesthetic. This aesthetic, this style, for all its seriousness still needs the balancing, heightening cry of mirth and pleasure that knows itself and its limits and knows both enough to say and to mean: wholan! Do we ever know ourselves truly enough in what we do - we men, or is rather for this author: we women of knowledge? If we were able to trace this esoteric connection further, would we find that the highest mirth and pleasure yokes fool and poet, finds song in the swan's choking death, and hears the first of music in that which sings of no sadness but the "sadness of the most profound happiness," (GS 183) or the joy which, Hölderlin's Sophoclean insight tells us, is the ultimate expression of tragedy? For whom?

Quoting his own "gaya scienza" in his description of the typology of Zarathustra in Ecce Homo, Nietzsche describes the new philosophers, the "men of knowledge," those of rare understanding conceived as he sought them with his tragic project of philosophic overtures as the "nameless, selfevident ... premature births of an as yet unproven future." For their very possibility in coming to be, for our own corresponding possibility to emerge as readers of Nietzsche's rare understanding, what is needed is what Nietzsche calls "great health." Such health is not possessed but inherited (or invented): it must be won and rewon and perpetually re-won because one "gives it up again and again, and must give it up." The highest will to power is distanced from rancor as its transformation on the basis of the sunlike benediction of Zarathustra's cultivated abundant power, a power that is not only beyond good and evil. Thus Zarathustra would have the love of the neighbor transformed into the love of the friend: "I teach you the friend in whom the world stands complete." In this artistic, aesthetic vision, Nietzsche conceives the image of the "creative friend who always has a complete world to give away." Such a vision as Nietzsche offers here reflects the height and the consequences of gift and benediction. From this tragic height alone may we see the advantage, see from the advantage of becoming in the turning of heroic blessing: "And as the world rolled apart from him, it rolls together again in circles for him, as the becoming of the good through evil, as the becoming of purpose out of chance."27

\section{Nietzsche's metaphysical nihilism: Adventavit asinus}

For Heidegger, Nietzsche's thought concerning nihilism underscores the emergent rule of the eminently technologizable, practical, material world by 
pronouncing the world of the metaphysical or the suprasensory, the world of the highest values dead or at an end, as nothing, that is, "without effective power." 28 In an Hegelian turn, Heidegger finds Nietzsche's antiPlatonic opposition to metaphysics remaining, necessarily "as does everything "anti," held fast in the essence of that over against which it moves." (WN 61) To see the truth of this claim beyond the movement of an Hegelian - and so Nietzsche-antipathic - opposition, it is necessary to consider Nietzsche's own insight into this same entanglement. ${ }^{29}$ If Nietzsche is not trapped by his own words, Heidegger's point has no purchase. Yet if Nietzsche is trapped, we nevertheless find that like the logical traps of his contradictory design concerning truth and the laws of physics, Nietzsche knows the dialectical conversion so well in advance that it is articulated in the turns of this very anticipation. Played with Nietzsche's fingers, logic now works uncannily against itself, as selfconstructed and so ultimately, effective self-deconstructive, that is a logic of expression styled to match and name nihilism. ${ }^{30}$ This conversion is effected by a reader-selective troping of the text that I name Nietzsche's concinni$t y^{31}$ The reference to the musicality of Nietzsche's philosophical style seeks to account for Nietzsche's deliberately styled question of the meaning of the past, of time and will, that is, again, of the relationship between being and becoming. Beyond Derrida and Foucault, beyond Ricoeur and Gadamer, to understand the project of Nietzsche's style, Nietzsche's musical challenges or turns, Heidegger is a thinker who for all his deliberate appropriation remains a reader able to read Nietzsche as one who knows what philosophy is, that is a fellow thinker, who shares the question of Being and of time, by exceeding it.

While Nietzsche recognized the force of mass culture as an expression of the will to technological power, this mass culture, the culture of nihilism, of dominion over the earth is not the expression of the overman. As noted in the preceding consideration of the elite or active character of the Will to Power, dominion as such cannot be the proper expression of the overman. The desire for dominion springs from the reactive desire born of a need for power. Thus lacking, mass or contemporary Western culture gives rise to the Zarathustran apothegm: "Man is something that must be overcome." The will to power that yields the culture of nihilism must be understood as more than the expression of a will to the revaluation of all values. The will of average, reactive, or mass culture is a consequence of deficiency. This is the will of the reactive, the weakened, the overshocked, the impotent. This will to power works in the sphere of existent values, it is the triumph of the ascetic ideal once again, and at all costs as Nietzsche describes this metamorphosis in The Genealogy of Morals.

But if Nietzsche classes the values of this ascetic will as slave values, it 
must never be forgotten that he also tells us that these are the very triumphant values of our time. Although it works in the service of life, the ascetic will refuses life. That is its paradox and for Nietzsche that is its ultimate, extreme danger: the danger of decadence. The life-denying will of the slave, of reactive humanity is not controlled by and can never be controlled by any active or master will. By virtue of its orientation and the tenacity of its drive for power, the reactive will is the most powerful will to power: "the weaker dominate the strong again and again - the reason being that they are the great majority, and they are also cleverer..." 32 For Nietzsche, in a decadent age,

nothing can last beyond the day after tomorrow, one species of man excepted, the incurably mediocre. The mediocre alone have the prospect of continuing on and propagating themselves - they are the men of the future, the sole survivors (BGE 262/182).

This reactive, measure, mediated species stands in opposition to the (vanished and largely impossible) noble type: the sovereign individual. It is only the sovereign individual who can command. Such a one, Heidegger reminds us, first gives the law to one's self (as Nietzsche says in the Genealogy of Morals, proposing this law and posing oneself before it, at one's own cost, with no other bond than one's body). With such freedom, such power to command is active revaluation or creation of values. The sovereign, artist's revaluation grows from the active affirmation of itself, the affirmation of a creative will.

The slave revaluation of values, on the other hand, is born of reaction: an "inversion of the value-posing eye," (GM 36) which brings any active power into its compass and so converts all pretensions to difference in the reactive spirit of its self-assertion. Its entrepreneurial creativity is based on denial of what is (this is realized by its technical, mechanical-manipulative dominion over nature and itself).

For Heidegger, Nietzsche's philosophy of Will to Power and the thought of the Eternal Return is a valorization of the latter reactive scheme of world domination, as the will to secure, "to seal Becoming with the character of Being." (WP 330) Commenting on Rilke's poetic word of untoward redemption, the protection (bergen) of our unshieldedess (Schutzlossein), Heidegger recalls that "Secure, securus, sine cura means: without care. The caring here has the character of purposeful self-assertion by the ways and means of unconditional production. We are without such care only when we do not establish our nature exclusively within the precinct of production and procurement, of things that cannot be utilized and defended." (WP 120) ${ }^{33}$ It is from out of the spirit of this secure responsiveness that "Nietzsche pondered the essence of that humanity which, in the destining of Being as 
the will to power, is being determined toward the assuming of dominion over the earth." (WN 98)

Heidegger's assertion here is fair enough in venture and vantage. The venture of high responsibility of the will to power that could support such an assumed dominion over the earth is the care of generosity in the extreme, while this in its turn requires the vantage of power in excess. But this dyad is a tricky one. Heidegger's point turns on a philosophical precision in Nietzsche's thought on the will to power and it is troublesome because of the easy equivocation which can collapse or fail to reflect the only indispensable force of Nietzsche's insight into the opposed registers of expression/acquisition articulating the universality of will to power.

As we have already seen, the technological project of "dominion over that which is as such" (WN 99) cannot for Nietzsche be the active but only the reactive project of the revaluation of values. Although Heidegger understands the distinction between action and reaction as the distinction between overflowing power as the expression of a will, he does not think the predominance of desperate neediness as the technic of a will. The essence of this distinction of the rule of a lack or a weakness corresponds to its rank-ordering: if the historical destiny of inadequacy is its desire for compensation and its triumph over all other values, it is not for that the highest value. In the order of rank, the highest value is literally above ordinary possibility; the hierarchy ascends from the esoteric to the exoteric.

Reading Heidegger's conception of nihilistic value and justice in the light of Nietzsche's constitutional polarization of will to power, nihilism is ambiguous because it corresponds to a devaluing of the highest values and at the same time to a "countermovement to devaluing." (WN 68) The will to power corresponds both to the expression of power and to the desire for power. The former, conceived as affirmation is only possible on the basis of abundance, the source of expression, while the latter desire for power grows out of the constraints of denial. In this last and most frequent circumstance of the will to power, power must be understood as a lack, and will to power thus understood is the occasion of preservative, accumulative desire. This same ambivalence is again double valued in accordance with the origin of revaluation. There is not only a revaluation of values that emerges on the basis of weakness (self-preservation) but there is also a revaluation born of strength (self-expression).

For Nietzsche, the fundamental tendency of organic being is a drive to expression: "A living thing desires above all to vent its strength - life as such is will to power -: self-preservation is only one of the indirect and most frequent consequences of it." (BGE 14/26) The life of superabundance seeks to express or expend its substance. Self-preservation may indeed result from such expression but it is inherently related to expression as such 
and indeed opposed to it. Expression expends power while preservation saves or conserves power. To say that self-preservation can be (even a frequent) result of such expression does not ameliorate its inherent incompatibility with the expression of power as such. One may not vent one's power while at the same time keeping it in reserve (conserving or preserving it). It is this essential opposition that makes the valorization of a life of abundant or creative self-expression fancifully romantic and ordinarily and for the most part tactically vain. Nietzsche's characterization of an era of revaluation fails to accord with the neediness of our times.

Opposing the aesthetic height of creative will to power, the contrary and preservational impulse of reactive will to power moves into an encircling sphere of world involvement and calculation which must always exclude Heidegger's expression of Nietzsche's redemptive triad - blunting the possibility of the hero's tragedy, unable to comprehend the satyr-play between earth and sky of the demi-god, denying the world-ringing God. In place of Nietzsche's hierarchic triad of aesthetic possibility, the reactive mode of inventive, technological will to power seeks the satisfaction of green pasture simplicity in its technological expression as dominion over the world of nature. Given Nietzsche's well-known emphasis upon the alltoo-in the excessively, ever-still-merely-human, it is not possible to say of all humans, as Heidegger seeks to categorize being human on the basis of the consciousness that "God is dead," that humanity is thereby in Hegelian fashion enabled to pass "over into another history that is higher, because in it the principle of value-positing, the will to power, is experienced and accepted expressly as the reality of the real, as the Being of everything that is." (WN 95) Such a realization may be possible for creative beings, for artists and as the self-realization of artists. But let us not forget that for Nietzsche most of us, as knowers, whether we can claim to be artists or not, "are unknown to ourselves." 34

To know ourselves, to remember ourselves, to cry out of ourselves and to laugh at ourselves is to begin to dance with light feet. It is this that is to regain the delight one had as a child at play. But we cannot embrace the romantic dilletante's or the more recent version of this romanticism in the new-age ethos of just-so self-invention, nor follow Alexander Nehamas's well intentioned reading of Nietzsche: Life as Literature. To give style to one's character as Nietzsche prescribes, is not only not prescribed for everybody but is so reserved for a reason. That reason is pain, it is in this way that thinking, that poetry is, here once again, hard. The laughter of the Nietzschean artist may not be thought as a laughter without pain, without terrible sacrifice, without cruelty to oneself and to others. Thus as Nietzsche says this ideal of "superhuman wellbeing and benevolence ... will often appear inhuman." (EH:Z, 2) Neither can the dance be thought without the 
stumbling fall, the crippling repetition, the exhaustion of body and soul for one end, neither can word be thought without the stammer, the never exhausted failure of foolishness, and the empty echo. Even the music Nietzsche celebrates is not immune where he can write of his anguish concerning the fate of music that it can be and "has been done out of its world-transfiguring, Yes-saying character, so that it is music of decadence and no longer the flute of Dionysus," (EH:CW, 1; 317) and where even music turns into decay, the hurdy gurdy song, silence is almost the only pure tone and we find that even that is awkward. Again: only we have created the world that concerns man. We have seen this ambiguity before in speaking of the essence of poetry, the spirit of music as the saving power. Here again the same ambiguous laughter of chance and delight - at what is in its glory and its bitter misery, where glory itself is nothing save such misery transformed by the "grand style," by heroic pride, by magnanimity and affirmation in expressing, at disposing of the powers in oneself, by joy - is also the only key to the "proud happiness" Nietzsche at the end of his life would call the fierce halcyon joy of the creator: "the halcyon, the light feet, the omnipresence of malice and exuberance." This Zarathustra is "eloquence become music." (EH: Z, 6, p. 305) $)^{35}$

For Nietzsche, "playing and brass," eloquence and vulgarity, delight and horror may not be separated. More than that, "malice and exuberance," cruelty and creation go together and this is no accident of human earthbound creativity. Thus, Zarathustra echoes the spirit of Nietzsche's first reflections on The Birth of Tragedy: "as deeply as man sees into life, he also sees into suffering." (Z:III, ON 2) In a resonant, reader-evocative, reader echoing concinnous turn, Nietzsche reminds us that even in such words "there is much playing and brass. He that has ears to hear, let him hear."

What must be underlined here is the self-conscious teasing challenge, the awareness of limit and prescription, of the absurd dominance of one's convictions. For Nietzsche, "to put it in the words of an ancient Mystery: adventavit asinus, pulcher et fortissimus." (BGE 8) Later in order to introduce his notorious and lengthy fugue against "women as such" in the same text, Nietzsche identifies such "convictions" as "signposts" to the "great stupidity which we are ... the unteachable 'right down deep'." (BGE 231) This perspective on one's convictions articulates the supreme nuance between the illusion of truth and the truth of illusion. Only the latter is art and only this can be music. Only the artist who deals in his illusions without illusion, with irony and mirth, be this artist of life philosopher or dancer, musician or poet-fool, can be the artist, the new technician of Nietzsche's re-valuation of values. As Nietzsche's diamond device reminds us here, "if your hardness does not wish to flash and cut and cut through, how can you one day create with me?" (Z:III ON 29) For, when one philosophizes with a 
hammer, after Nietzsche, post-Nietzsche as we are, are we not at last, at least able to relinquish the current conviction, the cultural current of conviction in our still-present fear of dissolution, that such a nihilism, such a dominion, such a declared promise and intention towards a lordship over the earth ("I am prepared to rule the world!) is spoken, if only in part than still at least this far: in jest. What more do we need, past, post-Nietzsche?

Not that Nietzsche does not "mean" to be taken seriously, that is not the point here, but much rather that after an exchange, a dialectic, an incorporative rumination upon and with this philosopher of grand phrasings (and this fine, resonant schema surely describes Nietzsche's good readers, such as we are, all of us) we should be able to think back on the achievement of style to wonder, to ask how it is, after all, that words, that human beings can overcome themselves? If Nietzsche sings of the dancing star born to beings that play with stars and who have always played with stars, whether they knew it or not, what he celebrates is the depth of the world, the lens of life. This is the dancing shimmering light, the irridescent happiness, the song of sadness welling on the surface, tears shining in the darkness, the sun's gold on the fisherman's oar, light feet over an abyss.

\section{Notes}

1. Michael Theunissen, "Was heute ist. Über Not und Notwendigkeit des Umganges mit Heidegger," in Martin Heidegger: Fragen an sein Werk. Ein Symposion (Stuttgart: Reclam, 1977), p. 21.

2. Eric Blondel, Nietzsche le corps et la culture (Paris 1986).

3. For Blondel's suggestion see the first three chapters of his Nietzsche le corps et la culture, trans. Seán Hand, Nietzsche: The Body and Culture, Philosophy as Philological Genealogy (London: Athlone Press, 1991; Stanford: Stanford University Press, 1991). For Safranski, see Rüdiger Safranski, Wieviel Wahrheit braucht der Mensch? Über das Denkbare und das Lebbare. (München/Wien: Carl Hanser, 1990), p. 71.

4. "For manifestly you have long been aware of what you mean when you use the expression "being." We, however," concludes Heidegger's introductory quote taken from Plato's Sophist, "who used to think we understood it, have now become perplexed." Thus Heidegger's first paragraph for the first to the last sentence in his introduction to Being and Time, expositing the "Question of the Meaning of Being" accuses the whole philosophical tradition of forgetfulness and trivializing. Being and Time, trans. Macquarrie and Robinson. (New York: Harper \& Row, 1962), quote p. 19/1 SZ

5. Martin Heidegger, Nietzsche. Volume One: The Will to Power as Art, trans. D. F. Krell (New York: Harper \& Row, 1979), p. 4. [Heidegger, Nietzsche: I (Pfullingen: Neske, 1961), p. 12.] Hereafter, references to the German edition will be made with a separating virgule following page references to the English language translation.

6. Ibid. 
7. Cf. David Allison's "Preface" to The New Nietzsche.

8. Heidegger, Nietzsche: 1, p. 4/p. 12.

9. Heidegger, Nietzsche: 1 , p. xvi/p. 10.

10. Heidegger, "The Question Concerning Technology," in The Question Concerning Technology, trans. W. Lovitt (New York: Harper \& Row, 1979), p. 33. Henceforward abbreviated QT.

11. Heidegger, "The Origin of the Work of Art," in Albert Hofstadter, Poetry, Language, Thought, p. 52. Henceforward abbreviated as WA, with page numbers inserted into the text.

12. "Enframing...threatens to sweep man away into ordering as the supposed single way of revealing, and so thrusts man in the danger of the surrender of his free essence [but] it is precisely in this extreme danger that the innermost indestructible belongingness of human being within the granting may come to light, provided that we for our part, begin to pay heed to the coming to presence of technology." (QT 32).

13. "On the one hand, Enframing challenges forth into the frenziedness of ordering that blocks every view into the coming-to-pass of revealing and so radically endangers the relation to the essence of truth. On the other hand, Enframing comes to pass for its part in the granting that lets man endure...that he may be the one who is needed and used for the safekeeping of the coming to presence of truth." (QT 33)

14. Heidegger, “...Poetically Man Dwells...” in Poetry, Language, Thought, p. 213. Henceforward abbreviated as $P$.

15. Heidegger, "The Turning" in The Question Concerning Technology, p. 47. Henceforward abbreviated QT/T.

16. Heidegger, "...das ich nicht gegen die Technik bin..." p. 25 in "Das Fernseh Interview" in Antwort: Martin Heidegger im Gespräch, hrsg. G. Neske, E. Kettering (Pfullingen: Neske, 1988).

17. T. S. Eliot, The Wasteland: V.

18. Hölderlin, "Der Einzige" Erster Fassung, trans. Richard Sieburth, "I never achieve the measure I wish. But a god knows when the best I wish comes true."

19. Hölderlin, Patmos, Bruchstücke der späteren Fassung, trans. Michael Hamburger, "For to be pure is a skill, a life that has a heart, in the presence of such a face, and outlasts the middle. Buch much is to be avoided."

20. Ja, die Frühlinge brauchten dich wohl. Es muteten manche

Sterne dir zu, daß du sie spürtest. Es hob

sich eine Woge heran im Vergangenen, oder

da du voriiberkamst am geöffneten Fenster,

gab eine Geige sich hin. Das alles war Auftrag.

Rainer Maria Rilke, Duino Elegies: $I$.

21. Hölderlin, Patmos, trans. M. Hamburger, "And there's no harm if some of it is lost."

22. Because such a deliberate philosophy of opposition as Nietzsche's elicits denigration in the established tradition of philosophy from Aristotle to Wittgenstein, Davidson and even Derrida, Nietzsche's voice is heard in the tones of fancy or poetry. On the other side, Nietzsche lacks a philosophical voice because of the resonant impoverishment of tradition. Hence Nietzsche finds himself closest to the Presocratic thinker known for his own esoteric darkness: Heraclitus, while, let it be noted, the issue of value must be decided 
between the two names Anaximander and Empedocles.

23. It is relevant that this elitism has found little correspondence, hardly any recognition or confirming, echoing resonance within the leagues even of Nietzsche's most fervent interpreters.

24. Martin Heidegger, "The Word of Nietzsche: God is Dead," in William Lovitt, trans. The Question Concerning Technology and Other Essays (New York: Harper \& Row, 1977), p. 67. Henceforward abbreviated as WN, with page numbers inserted into the text.

25. Nietzsche, The Gay Science, 301. trans. W. Kaufmann (Random House: New York, 1974), p. 242. Henceforward abbreviated as GS, with page numbers inserted into the text.

26. Heidegger, Beiträge zur Philosophie. Vom Ereignis (Frankfurt a/M.: Klostermann, 1989), p. 107.

27. Z:I, "On Love of One's Neighbor." Modified translation.

28. Heidegger, "The Word of Nietzsche: God is Dead," p. 61. Henceforward abbreviated WN.

29. The value of Heidegger's claim of entanglement is not disputed here: it is patently and in Heidegger's own sense: correct.

30. "Those who fancy themselves free of nihilism perhaps push forward its development most fundamentally." p. 63. This "uncanny guest" heralding the end of modernity's ambitious adventure in history.

31. See my "On Nietzsche's Concinnity: An Analysis of Style." Nietzsche-Studien 19 (1990):59-80).

32. Nietzsche, Twilight of the Idols, trans. R. J. Hollingdale (Harmondsworth and New York: Penguin, 1981), p. 76.

33. For Heidegger, "future thinking" must be tempered by the character of what he names, counting on the resonance of his earlier notion of anticipatory resolve, or authenticity a "high responsibility." This "high responsibility" may be understood as a charge linking the early Heidegger's expression of "care" (Sorge) in Being and Time with his later more ambivalent expression of saving or protection, security. Heidegger cites Rilke's unfinished poem WP 99. The relevant German text runs as follows

...was uns schließlich birgt,

ist unser Schutzlossein und daß wirs so so

ins Offne wandten, da wirs drohen sahen,

um es, im weitesten Umkreis irgendwo,

wo das Gesetz uns anrührt, zu bejahen.

- Rilke, "improvisierte Verse, cited in Heidegger, "Wozu Dichter," Holzwege, (Frankfurt a.M.: Klosterman, 1950), p. 273.

34. Nietzsche, On the Genealogy of Morals, Preface. Even philosophers of the future, corresponding to Nietzsche's temporary schema, cannot always be conscious of what is created by their own artistic temperament or that their own cultivatedly aesthetic values are the fruit of both body and mortal soul. The thing about this kind of self-knowledge is that it excludes itself in its achievement.

35. Ecce Homo, "Thus Spoke Zarathustra": 6, p. 305 "In every word he contradicts, this most Yes-Saying of all spirits; in him all opposites are blended into a new unity. The highest and the lowest energies of human nature, what is sweetest and most frivolous, and most terrible wells forth from one fount with immortal assurance." 